\title{
Thermic effect of food in man: effect of meal composition, and energy content
}

\author{
BY J. L. KINABO AND J. V. G. A. DURNIN* \\ Institute of Physiology, University of Glasgow, Glasgow GI28QQ
}

(Received 3 July 1989 - Accepted 9 February 1990)

\begin{abstract}
The effect of meal composition and energy content on the thermic effect of food (TEF) was investigated in sixteen adult, non-obese female subjects. Each subject consumed four different test meals, each meal on a different day. Meals were of high-carbohydrate-low-fat (HCLF) with 0.70, 0.19 and 0.11 of the energy content from carbohydrate, fat and protein respectively, and low-carbohydrate-high-fat (LCHF) with $0.24,0.65$ and 0.11 of the energy content from carbohydrate, fat and protein respectively. The energy contents of the test meals for each composition were $2520 \mathrm{~kJ}(600 \mathrm{kcal})$ and $5040 \mathrm{~kJ}(1200 \mathrm{kcal})$. The basal metabolic rate (BMR) and the postprandial metabolic rate (PP-MR) were measured by open-circuit indirect calorimetry using the Douglas bag technique while the subjects were in the supine position. The mean BMR value was 3.63 (SE 0.07$) \mathrm{kJ} / \mathrm{min}(0.87 \mathrm{kcal} / \mathrm{min}$ (SE 0.017$)$ ). The $5 \mathrm{~h}$-TEF value for the $2520 \mathrm{~kJ}$ (600 kcal) HCLF meal was 228 (SE 11.8$) \mathrm{kJ}$ (54 kcal (SE 2.8)) and for the LCHF meal was 228 ( $\mathrm{SE} 9 \cdot 6) \mathrm{kJ}$ (54 kcal (SE 2.3)). The corresponding values for the $5040 \mathrm{~kJ}$ (1200 kcal) meals were 356 (SE 20.4) kJ (85 kcal (SE 4.9)) and 340 (SE 15.8) kJ (81 keal (SE 3.8)). There was no significant $(P=$ $0.49)$ effect of meal composition on TEF, but the energy content of the meals had a significant $(P<$ 0.001) effect on TEF. In all subjects and for all meals, PP-MR had not returned to premeal level $5 \mathrm{~h}$ after a meal, indicating that the TEF values measured underestimate total TEF. The present study suggests that TEF is significantly influenced by the energy content of a meal but not by meal composition.
\end{abstract}

Thermic effect of food: Meal composition: Energy content

The thermic effect of food (TEF) is defined as the increase in metabolic rate (MR) following ingestion of a meal. This increase in MR has been associated with the obligatory energy cost of digestion, absorption and storage of nutrients in the body. There is increasing evidence that TEF may have a regulatory component which is mediated through the sympathetic nervous system (Landsberg \& Young, 1983) and some hormones such as insulin (Ravussin et al. 1985), thyroid (Ingbar \& Braverman, 1986), and catecholamine (Landsberg \& Young, 1983). Although TEF has been investigated extensively, its quantitative role in the overall energy balance of man is still unclear. Both the mechanisms that underly its production and the factors that influence its magnitude are poorly understood. Knowledge of the effect of such factors on TEF is important in understanding the role of TEF in the overall energy balance under different nutritional conditions.

Various factors including age (Morgan \& York, 1983), exercise (Segal \& Gutin, 1983), nutritional status (Brooke \& Ashworth, 1972; Garrow, 1986), energy content of a meal (Clough \& Durnin, 1970; Belko et al. 1986; Belko \& Barbieri, 1987), and meal composition (Garrow \& Hawes, 1972; Schwartz et al. 1985) have been shown to influence TEF.

Of these factors, meal composition and energy content are of particular interest because their relative effects on TEF reported from different studies differ widely. Although meal composition has been reported to influence TEF (Garrow \& Hawes, 1972; Welle et al.

\footnotetext{
* For reprints.
} 
1981; Dauncey \& Bingham, 1983; Schwartz et al. 1985), several studies have shown that TEF is not influenced by meal composition (Miller et al. 1967; Pittet et al. 1974; Rosenberg \& Durnin, 1978; Hurni et al. 1982; Belko et al. 1986). While several investigators have shown that TEF is directly related to the energy content of a meal (Hill et al. 1984; Karst et al. 1984; Belko et al. 1986), others have failed to establish any relationship between TEF and energy content of a meal (Glickman et al. 1948; Bradfield \& Jourdan, 1973). The reasons for these different results are not clear. However, methodological differences as well as the type and form of meals used may partly account for the different results among laboratories.

Protein has been regarded as the most thermogenic nutrient; therefore, its proportion in the diet has been shown by some workers to have a significant effect on TEF (Dauncey \& Bingham, 1983; Zed \& James, 1986). However, other workers have observed no significant difference in TEF between meals containing different proportions of protein (Bradfield \& Jourdan, 1973; Belko et al. 1986). Moreover, it has been demonstrated that the increase in energy expenditure associated with food does not appear to result from an increase in protein synthesis (Garlick, 1986) or urea formation (Garrow \& Hawes, 1972).

In the present study, we examined the effect on TEF of two factors, namely: (1) meal composition: high-carbohydrate-low-fat (HCLF) and low-carbohydrate-high-fat (LCHF), and (2) energy content of the ingested meal: $2520 \mathrm{~kJ}(600 \mathrm{kcal})$ and $5040 \mathrm{~kJ}$ $(1200 \mathrm{kcal})$. The two compositions of the test meals were chosen to represent the two extreme diets eaten in different societies.

\section{METHODS}

\section{Subjects}

Sixteen healthy, adult, non-obese female subjects participated in the study. None was taking any medication during the period of the study. Their physical characteristics are presented in Table 1. There were no significant differences among subjects in terms of age, weight, height, body fat and fat-free mass (FFM).

Subjects were instructed to abstain from food and drinks (especially caffeine-containing beverages as well as alcohol) by 20.00 hours on the night preceding each test day and not to eat anything the following morning, and also to keep a record of food eaten and activities carried out on the day preceding each test day. All subjects were familiar with the protocol by the time of the experiment.

\section{Test meals}

Four different test meals (A, B, C, D) were used. Meals A and C were of HCLF containing $2520 \mathrm{~kJ}(600 \mathrm{kcal})$ and $5040 \mathrm{~kJ}(1200 \mathrm{kcal})$ respectively, with $0 \cdot 70,0.19$ and 0.11 of the energy from carbohydrate, fat and protein. Meals B and D were of LCHF containing $2520 \mathrm{~kJ}(600 \mathrm{kcal})$ and $5040 \mathrm{~kJ}(1200 \mathrm{kcal})$ respectively, with $0.24,0.65$ and 0.11 of the energy content from carbohydrate, fat and protein. Meals were composed of ordinary food items, namely: cornflakes, brown bread, cheese, butter, marmalade, jam, orange juice and double cream, and were administered in the form in which they are normally eaten. The energy content and nutrient composition were computed using the food composition tables of McCance and Widdowson (Paul \& Southgate, 1978).

\section{Determination of basal $M R(B M R)$}

We have described the initial measurement as being that of BMR. What exactly constitutes the conditions under which BMR is measured seems to have become in the recent past the source of confusion, and the impression seems to have arisen that BMR implies that the 
Table 1. Physical characteristics of subjects

(Mean values with their standard errors)

\begin{tabular}{|c|c|c|c|}
\hline & Mean & $\mathrm{SE}$ & Range \\
\hline Age (years) & 22 & $1 \cdot 5$ & $18-40$ \\
\hline Height (m) & $1 \cdot 64$ & $0 \cdot 01$ & $1.56-1.74$ \\
\hline Weight $(\mathrm{kg})^{*}$ & $55 \cdot 8$ & $0 \cdot 9$ & $50 \cdot 1-61 \cdot 6$ \\
\hline Body fat $(\mathrm{g} / \mathrm{kg}$ body-wt) $\dagger$ & 240 & 6 & $200-280$ \\
\hline FFM $(\mathrm{kg})$ & $42 \cdot 9$ & 0.8 & $39-0-47 \cdot 8$ \\
\hline BMI $\left(\mathrm{kg} / \mathrm{m}^{2}\right)$ & $20 \cdot 8$ & $0-04$ & $18 \cdot 6-23 \cdot 4$ \\
\hline BMR (kJ/kg FFM per d) & 124 & $0 \cdot 5$ & $110 \cdot 0 \cdot 140 \cdot 0$ \\
\hline
\end{tabular}

BMI, body mass index; BMR, basal metabolic rate; FFM, fat free mass.

* Average of weights recorded on four different days.

$\dagger$ Estimated from four skinfold thicknesses (biceps, triceps, subscapular and suprailiac) by the method of Durnin \& Womersley (1974).

subject has been admitted to a hospital or to a metabolic unit or chamber the night before and BMR is measured before getting out of bed in the morning. Whatever the rationale of this view (and for many people this procedure might easily constitute a disturbing experience) this is not how almost all the fundamental work on BMR was carried out (Benedict, 1915; du Bois, 1927; Boothby et al. 1936). An extract from the book by E. F. du Bois (1927) on Basal Metabolism in Health and Disease describes the requirements: ' $\mathrm{He}$ must be instructed to take no food in the evening after 8 o'clock and nothing in the morning except a cup of caffeine-free coffee without milk or sugar. He must be brought to the laboratory without fatigue, he must lie quietly for at least one half hour before the test. The atmosphere of the room should be quiet and confident.' These are precisely the conditions under which BMR was measured in our study. On the day of the experiment, subjects reported to the laboratory at 08.00 hours after an overnight fast. The subject was weighed and then rested lying in bed in the supine position for $30 \mathrm{~min}$ in a room maintained at $18^{\circ}$. After 30 min rest the subject was fitted with a nose clip and mouth piece, and breathed through a Rudolph low resistance valve (no. 1400) for $3 \mathrm{~min}$. After the subject had become accustomed to breathing through the apparatus two 10 min samples of expired air were collected in Douglas bags. Expired air was analysed for oxygen and carbon dioxide content using a paramagnetic $\mathrm{O}_{2}$ analyser (type 570A SYBRON; Servomex Ltd, Crowborough, Sussex), and an infrared $\mathrm{CO}_{2}$ analyser (type 801-A; PK Morgan Ltd, Chatham, Kent).

The gas analysers were calibrated on each test day before and $3 \mathrm{~h}$ after the start of the experiment. First, they were set at zero using a guaranteed $\mathrm{O}_{2}$-free nitrogen (British Oxygen Co. Ltd, Great Westhouse, Brentford, Middlesex), and calibrated using guaranteed standard gas mixtures of $\mathrm{CO}_{2}-\mathrm{O}_{2}(4 \cdot 05: 16 \cdot 30, \mathrm{v} / \mathrm{v})$ and $\mathrm{CO}_{2}-\mathrm{O}_{2}(6 \cdot 06: 15 \cdot 62, \mathrm{v} / \mathrm{v})$. The span of the $\mathrm{O}_{2}$ analyser was calibrated using atmospheric air. The volume of expired air was measured by a Parkinson-Cowan respirometer (calibrated at 50-150 litres/min) and corrected for moisture at standard temperature and pressure, dry.

MR ( $\mathrm{kJ} / \mathrm{min}$ ) was calculated (Weir, 1949) for each bag, and if the difference between the two bags was not less than $3 \%$, a third sample of expired air was collected, analysed and MR calculated. The average MR calculated from these measurements was taken as representing the BMR of the subject. BMR was determined on each test day before the ingestion of a test meal. 


\section{Determination of post-prandial $M R(P P-M R)$}

After the BMR determinations were completed, the subject consumed one of the test meals, which had to be consumed within $10 \mathrm{~min}$ if it contained $2520 \mathrm{~kJ}(600 \mathrm{kcal})$ or within $20 \mathrm{~min}$ if the meal contained $5040 \mathrm{~kJ}(1200 \mathrm{kcal})$. Each subject consumed four different test meals on separate occasions. The order of presentation of the meals was randomized separately for each subject.

PP-MR measurements were started $10 \mathrm{~min}$ after complete ingestion of the test meal. Samples of expired air were collected intermittently for a period of $300 \mathrm{~min}$. The first three measurements were taken at $10 \mathrm{~min}$ intervals, and the next five measurements at $20 \mathrm{~min}$ intervals.

Expired air was collected, analysed and MR calculated as described previously. The average values obtained from the two bags were taken as representing the PP-MR at each time a measurement was made. For each subject, the increase in MR above BMR $(\mathrm{PP}-\mathrm{MR}-(\mathrm{BMR})) v$. time was plotted. TEF was calculated as the area under the increase in MR $v$. time curve using the trapezoidal method.

To avoid discomfort from prolonged use of the mouthpiece and nose clip, these were removed between measurements (rest period). However, they were again fitted to the subject during the last $3 \mathrm{~min}$ of the rest period to ensure that the subject was supine, quiet, relaxed and breathing comfortably through the valve before gas collection. Subjects were allowed to read, listen to music or watch television between measurements, but were requested to remain supine most of the time, and to remain absolutely immobile during the actual measurement.

\section{Statistical analysis}

The results were assessed by $2 \times 2$ factorial analysis of variance (ANOVA). The premeal BMR values and the overall PP-MR values were compared by Student's paired $t$ test.

\section{RESULTS}

\section{$T E F$}

The mean BMR and the $5 \mathrm{~h}$ TEF values of the four test meals are presented in Table 2. The mean BMR values were similar in all test meal situations with an average of 3.63 (SE. 0.07$) \mathrm{kJ} / \mathrm{min}(0.86 \mathrm{kcal} / \mathrm{min}(\mathrm{SE} 0.017)$ ) or 124 (SE 0.45$) \mathrm{kJ} / \mathrm{kg}$ FFM per d. The mean coefficient of variation (CV) in BMR for individual subjects was $5 \%$ (range $1-10 \%$ ), indicating good reproducibility.

As expected, all subjects showed a significant increase in MR after all test meals (Fig. 1). The overall mean increases in MR after $2520 \mathrm{~kJ}(600 \mathrm{kcal})$ meals were $0.79 \mathrm{~kJ} / \mathrm{min}$ $(0.19 \mathrm{kcal} / \mathrm{min})(95 \%$ confidence interval (CI) $0.71,0.85)$ for the HCLF meal and $0.79 \mathrm{~kJ} / \mathrm{min}(0.19 \mathrm{kcal} / \mathrm{min})(95 \% \mathrm{CI} 0.71,0.86)$ for the LCHF meal. The corresponding values for the $5040 \mathrm{~kJ}(1200 \mathrm{kcal})$ meals were $1.26 \mathrm{~kJ} / \mathrm{min}(0.30 \mathrm{kcal} / \mathrm{min})(95 \% \mathrm{CI} 1 \cdot 17$, $1.34)$ and $1.21 \mathrm{~kJ} / \mathrm{min}(0.29 \mathrm{kcal} / \mathrm{min})(95 \% \mathrm{CI} 1.17,1.31)$. This corresponded to an increase of 21 and $33 \%$ above the BMR for the $2520 \mathrm{~kJ}(600 \mathrm{kcal})$ and $5040 \mathrm{~kJ}(1200 \mathrm{kcal})$ meals respectively.

The 5 h-TEF mean values were 228 (SE 11.8) kJ (54 kcal (SE 2.8)) and 228 (SE 9.6) kJ (54 kcal (SE 2-3)) for the $2520 \mathrm{~kJ}(600 \mathrm{kcal}) \mathrm{HCLF}$ and LCHF meals respectively. Those for the $5040 \mathrm{~kJ}(1200 \mathrm{kcal})$ meals were $356(\mathrm{SE} 20 \cdot 4) \mathrm{kJ}(85 \mathrm{kcal}(\mathrm{SE} 4.9))$ and 340 (SE 15.8) kJ (81 kcal (SE 3.8)) for the HCLF and LCHF meals respectively.

There was no significant effect of the meal composition on TEF (F 0.49, $P$ 0.49). However, the energy content of the test meals had a significant effect on TEF $(F 115 \cdot 8$, $P<0.001$ ), with meals of higher energy content having $5 \mathrm{~h}$-TEF values significantly greater 
Table 2. Basal metabolic rate $(B M R)$ and the thermic effect of food $(T E F)$ of female subjects (n 16) after ingesting four different test meals

(Mean values with their standard errors)

\begin{tabular}{|c|c|c|c|c|c|c|c|c|c|}
\hline \multirow{2}{*}{\multicolumn{2}{|c|}{ Meals... }} & \multicolumn{2}{|c|}{ A } & \multicolumn{2}{|c|}{ B } & \multicolumn{2}{|c|}{$C$} & \multicolumn{2}{|c|}{$D$} \\
\hline & & Mean & $\mathrm{SE}$ & Mean & $\mathrm{SE}$ & Mean & $\mathrm{SE}$ & Mean & SE \\
\hline BMR & $\begin{array}{l}\mathrm{kJ} / \mathrm{min} \\
\mathrm{kcal} / \mathrm{min}\end{array}$ & $\begin{array}{l}3 \cdot 70 \\
0 \cdot 88\end{array}$ & $\begin{array}{l}0 \cdot 3 \\
0 \cdot 1\end{array}$ & $\begin{array}{l}3.65 \\
0.87\end{array}$ & $\begin{array}{l}0 \cdot 3 \\
0 \cdot 1\end{array}$ & $\begin{array}{l}3 \cdot 69 \\
0.88\end{array}$ & $\begin{array}{l}0 \cdot 3 \\
0 \cdot 1\end{array}$ & $\begin{array}{l}3 \cdot 47 \\
0 \cdot 83\end{array}$ & $\begin{array}{l}0.3 \\
0.1\end{array}$ \\
\hline TEF & $\begin{array}{l}\mathrm{kJ} / 5 \mathrm{~h} \\
\mathrm{kcal} / 5 \mathrm{~h} \\
\% \mathrm{BMR} \\
\% \mathrm{EI}\end{array}$ & $\begin{array}{r}228 \\
54 \\
21 \cdot 0 \\
9 \cdot 0\end{array}$ & $\begin{array}{c}12 \\
3 \\
1 \cdot 1 \\
0.5\end{array}$ & $\begin{array}{r}228 \\
54 \\
21 \cdot 0 \\
9 \cdot 0\end{array}$ & $\begin{array}{c}14 \\
2 \\
1.5 \\
0.6\end{array}$ & $\begin{array}{l}356 \\
85 \\
33 \cdot 0 \\
7 \cdot 0\end{array}$ & $\begin{array}{l}20 \\
5 \\
2 \cdot 0 \\
0 \cdot 4\end{array}$ & $\begin{array}{c}340 \\
81 \\
33 \cdot 0 \\
7 \cdot 0\end{array}$ & $\begin{array}{l}16 \\
4 \\
1 \cdot 6 \\
0 \cdot 3\end{array}$ \\
\hline
\end{tabular}

EI, energy intake; A, high-carbohydrate-low-fat $2520 \mathrm{~kJ}(600 \mathrm{kcal})$ meal; B, low-carbohydrate-high-fat $2520 \mathrm{~kJ}$ $(600 \mathrm{kcal})$ meal; C, high-carbohydrate-low-fat $5040 \mathrm{~kJ}$ (1200 kcal) meal; D, low-carbohydrate-high-fat $5040 \mathrm{~kJ}$ (1200 kcal) meal.

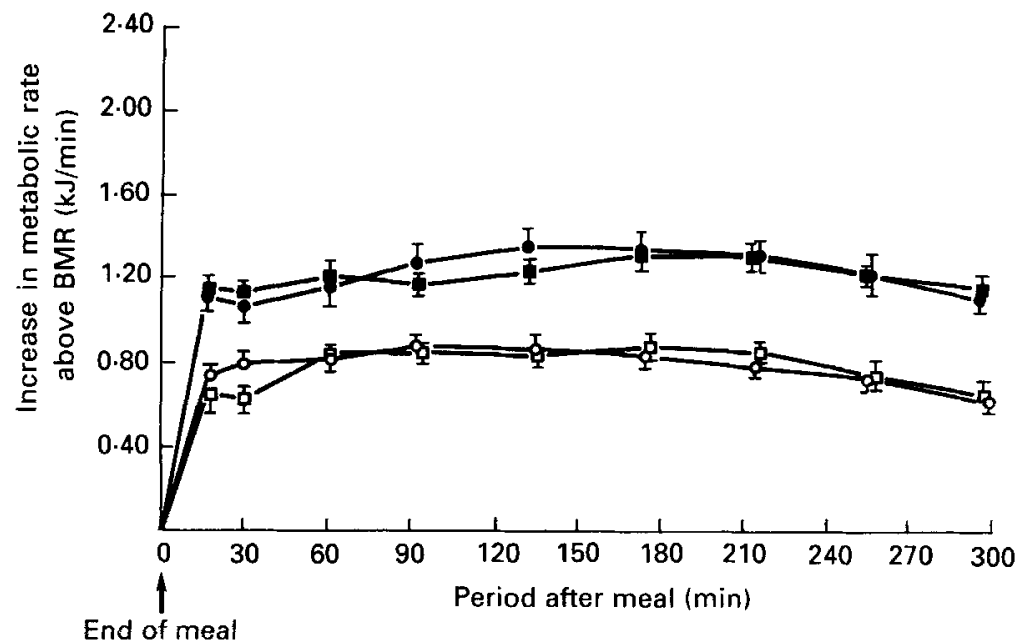

Fig. 1. Increase in metabolic rate above basal metabolic rate (BMR) $(\mathrm{kJ} / \mathrm{min})$ after ingestion of four different test meals by human subjects: $(O)$ high-carbohydrate-low-fat $(2520 \mathrm{~kJ}(600 \mathrm{kcal})),(\square)$ low-carbohydrate-high-fat $(2520 \mathrm{~kJ}(600 \mathrm{kcal}))$, (O) high-carbohydrate-low-fat $(5040 \mathrm{~kJ}(1200 \mathrm{kcal}))$, (兄) low-carbohydrate-high-fat $(5040 \mathrm{~kJ}(1200 \mathrm{kcal}))$.

than those for the low-energy content. Meal composition and energy content did not show significant interaction in influencing TEF $(F 0.45, P=0.50)$.

The $5 \mathrm{~h}$-TEF values expressed as percentage of energy content of the ingested meals were $9 \%$ for the $2520 \mathrm{~kJ}(600 \mathrm{kcal})$ and $7 \%$ for the $5040 \mathrm{~kJ}(1200 \mathrm{kcal})$ meals. Since total TEF was not measured, TEF obtained here underestimate to some degree (especially after the $5040 \mathrm{~kJ}$ meals) the total percentage of the energy content of the meal actually expended for TEF.

\section{Subjects variability}

There was significant inter-subject variability in TEF values $(F 5 \cdot 16, P<0 \cdot 001$, coefficient of variation (CV) $18 \cdot 6-24 \cdot 6 \%$ ). 


\section{DISCUSSION}

\section{Effect of meal composition on TEF}

The present study did not establish any relationship between meal composition and TEF. There were no significant differences in the $5 \mathrm{~h}$-TEF values between HCLF and LCHF meals. Our results agree with those of other studies (Pittet et al. 1974; Rosenberg \& Durnin, 1978; Belko et al. 1986). However, other workers have reported significant differences in TEF values between meals of different composition (Dauncey \& Bingham, 1983; Schwartz et al. 1985; Zed \& James, 1986). The reasons for the differences are not clear. It is probable that methodological differences as well as the form and type of meals used may partly account for such differences.

In most studies, either $100 \%$ pure single nutrients (Pittet et al. 1974), pure mixed nutrients (Pittet et al. 1974), single nutrient meals (Garrow \& Hawes, 1972; Welle et al. 1981 ) or mixed meals (Swindells, 1972; Rosenberg \& Durnin, 1978; Dauncey \& Bingham, 1983; Schwartz et al. 1985; Belko et al. 1986) were used to examine TEF in man. Of these, only a few used solid meals (Swindells, 1972; Rosenberg \& Durnin, 1978; Dauncey \& Bingham, 1983). In the present study, meals were presented in the form in which they are normally eaten.

The effect of meal composition on TEF has been examined at only one level of energy intake (Schwartz et al. 1985). In the present study, we examined the effect of meal composition at two levels of energy intake $(2520 \mathrm{~kJ}(600 \mathrm{kcal})$ and $5040 \mathrm{~kJ}(1200 \mathrm{kcal}))$. At both levels, meal composition did not have any significant effect on TEF. This is surprising, as we had expected that at high levels of energy intake the HCLF meal would stimulate more thermogenesis than the LCHF meal since more energy is required for the storage of carbohydrate than fat (Flatt, 1978; Garrow, 1978; Acheson et al. 1984).

\section{Effect of energy content on TEF}

In the present study, meals of high energy content $(5040 \mathrm{~kJ}(1200 \mathrm{kcal}))$ had TEF values significantly greater than those of low energy content $(2520 \mathrm{~kJ}(600 \mathrm{kcal}))$. Our results are in accord with those reported from other studies (Hill et al. 1984; Karst et al. 1984; Belko et al. 1986). However, other workers have observed no significant differences in TEF values between meals of different energy content (Swindells, 1972; Bradfield \& Jourdan, 1973; Bray et al. 1974). The results obtained here suggest that the magnitude of TEF is directly related to the energy content of the ingested meal.

When the $5 \mathrm{~h}$-TEF values were expressed as a percentage of the energy content of the ingested meals, they were found to be lower ( 9 and $7 \%$ respectively) than the estimated $10 \%$ (Ravussin et al. 1985). Since total TEF was not measured, the values obtained here underestimate the actual amount of energy expended for TEF and the values could be greater than the estimated $10 \%$. However, the values are consistent with those reported by other workers. Miller et al. (1967) reported TEF values which were 7-10\% of the energy content of 1550-13440 kJ meals. Similarly Belko \& Barbieri (1987) observed that the TEF values were $5-7 \%$ of the energy content of $6000-8300 \mathrm{~kJ}$.

The $5 \mathrm{~h}$-TEF values obtained in the present study were 21 and $33 \%$ above the BMR for the $2520 \mathrm{~kJ}(600 \mathrm{kcal})$ and $5040 \mathrm{~kJ}(1200 \mathrm{kcal})$ meals respectively. These results are similar to those reported by other workers using meals of the same energy content (Miller et al. 1967; Swindells, 1972; Rosenberg \& Durnin, 1978; Dalloso \& James, 1982), and taken together they seem to suggest that TEF measured under resting conditions may attain a magnitude equivalent to one quarter of the BMR $(0 \cdot 25 \times \mathrm{BMR})$. This cannot be considered insignificant as has been suggested (Swindells, 1972; Garrow, 1978; Davidson et al. 1979). The results of Schwartz et al. (1985) are in accord with our findings. 
Subjects variability

There was marked inter-subject variability in the $5 \mathrm{~h}$-TEF values (CV 19-25\%). This was surprising because there were no significant differences among subjects in terms of weight, FFM and fat content. The reasons for the variations are unclear. However, it may be speculated that this variation could be due to inherent differences with regard to efficiency in digestion, absorption and disposition of nutrients in the body.

\section{Duration of $T E F$}

It is evident that the TEF measured under resting conditions in the present study constituted a significant increase in MR. However, it is possible that the overall quantitative importance of TEF could have been underestimated, especially that of the $5040 \mathrm{~kJ}$ (1200 kcal) meals, because none of the subjects studied had her MR value returned to baseline $5 \mathrm{~h}$ after the meal. Other studies have also made similar observations (Schwartz et al. 1985; Belko \& Barbieri, 1987). One overfeeding study (Schutz et al. 1985) showed that TEF was prolonged, and that it lasted not only for the whole day but also throughout the night until the following morning, when the effect was still apparent.

From these results, and considering the average feeding pattern (three meals/d), there is strong indication that the TEF of one meal merges into the TEF of the next meal.

The reasons for this prolonged effect are unknown. However, it is pertinent to assume that the presence of food in the body stimulates various biosynthetic and oxidation processes. Although these processes take place all the time, their rate increases (selfaccelerating) immediately after a meal because of the high influx of nutrients to the cells. These processes will proceed at a diminishing rate until all the nutrients have been processed and stored. According to Flatt (1978), even after the nutrients have been stored there is a certain probability of being reutilized in the biosynthetic processes. Nutrient intake, therefore, depending on the amount to be processed, will increase energy expenditure far beyond the postprandial phase. If this theory is true, then it will help to explain the prolonged response observed here (especially with the high-energy meals) and in other studies as well.

The authors would like to thank Mr J. Wilson and Mr P. Patterson for technical assistance, Dr D. McLaren of the Statistics Department and Dr J. Currall of Computer Science for helpful advice on statistical analysis, and Sokoine University of Agriculture, Morogoro, Tanzania for financial assistance.

\section{REFERENCES}

Acheson, K. J., Schutz, Y., Bessard, T., Ravussin, E., Jequier, E. \& Flatt, J. P. (1984). Nutritional influences on lipogenesis and thermogenesis after a high carbohydrate meal. American Journal of Physiology 246, E62-E70.

Belko, A. Z. \& Barbieri, T. F. (1987). Effect of meal size and frequency on the thermic effect of food. Nurtion Research 7, 237.242.

Belko, A. Z., Barbieri, T. F. \& Wong, E. C. (1986). Effect of energy and protein intake and exercise intensity on the thermic effect of food. American Journal of Clinical Nutrition 43, 863-869.

Benedict, F. G. (1915). Factors affecting basal metabolism. Journal of Biological Chemistry 20, $263-269$.

Boothby, W. M., Berkson, J. \& Dunn, H. L. (1936). Studies of the energy metabolism of normal individuals: a standard for basal metabolism, with a nomogram for clinical applications. American Journal of Physiology 116, 468-484.

Bradfield, R. B. \& Jourdan, M. H. (1973). Relative importance of specific dynamic action in weight-reduction diets. Lancet ii, 640-643.

Bray, G. A., Whipp, B. J. \& Koyal, S. N. (1974). The acute effects of food intake on energy expenditure during cycle ergometry. American Journal of Clinical Nutrition 27, 254-259.

Brooke, O. G. \& Ashworth, A. (1972). The influence of malnutrition on the post prandial metabolic rate and respiratory quotient. British Journal of Nutrition 27, 407-415. 
Clough, D. P. \& Durnin, J. V. G. A. (1970). The rise in metabolic rate following the ingestion of single large meals by 'thin' and 'average' men and women. Journal of Physiology 207, 89P.

Davidson, S., Passmore, R., Brock, J. F. \& Truswell, A. S. (1979). Human Nutrition and Dietetics, 7 th ed. London, Edinburgh and New York: Churchill Livingstone.

Dalloso, H. M. \& James, W. P. T. (1982). Whole-body calorimetry studies in adult men: the effect of fat overfeeding on the $24 \mathrm{~h}$ energy expenditure. British Journal of Nutrition 52, 49-64.

Dauncey, M. J. \& Bingham, S. A. (1983). Dependence of 24 h energy expenditure in man on the composition of the nutrient intake. British Journal of Nutrition 50, 1-13.

du Bois, E. F. (1927). Basal Metabolism in Health and Disease. Philadelphia: Lea \& Febiger.

Durnin, J. V. G. A. \& Womersley, J. (1974). Body fat assessed from total body density and its estimation from skinfold thickness measurement of 484 men and women from 16 to 72 years. British Journal of Nutrition 32. 77-97.

Flatt, J. P. (1978). The biochemistry of energy expenditure. In Recent Advances in Obesity Research, vol. 11, pp. 211-218 [G. A. Bray, editor]. London: Newman.

Garlick, P. J. (1986). Protein synthesis and energy expenditure in relation to feeding. International Journal for Vitamin and Nutrition Research 56, 197-200.

Garrow, J. S. (1978). The regulation of energy expenditure. In Recent Advances in Obesity Research, vol. 11, pp. $200-210$ [G. A. Bray, editor]. London: Newman.

Garrow, J.S. (1986). Chronic effect of over- and under-nutrition in thermogenesis. International Journal for Vitamin and Nutrition Research 56, 201-204.

Garrow, J. S. \& Hawes, S. F. (1972). The role of amino acid oxidation in causing 'SDA' in man. British Journal of Nutrition 27, 21 I-219.

Glickman, N., Mitchell, H. H., Lambert, E. H. \& Keaton, R. W. (1948). The total specific dynamic action of highprotein and high-carbohydrate diets on human subjects. Journal of Nutrition 36, 41-57.

Hill, J. O., Heymsfield, S. B., McMannus, C. \& Digirolamo, M. (1984). Meal size and thermic response to food in male subjects as a function of maximum aerobic capacity. Metabolism 33, 743-749.

Hurni, M., Bernand, B., Pittet, P. G. \& Jequier, E. (1982). Metabolic effects of a mixed and a high-carbohydrate low-fat diet in man, measured over $24 \mathrm{~h}$ in a respiratory chamber. British Journal of Nutrition 47, $33-42$.

Ingbar, S. H. \& Braverman, L. E. [editors] (1986). The Thyroid: a Fundamental and Clinical Text, 5th ed. Philadelphia: J. B. Lippincott Co.

Karst, H., Steiniger, J., Noack, R. \& Steglich, H. D. (1984). Diet-induced thermogenesis in man: thermic effect of single proteins, carbohydrates and fats depending on their energy amount. Annals of Nutrition and Metabolism 28, 245-252.

Landsberg, L. \& Young, J. B. (1983). The role of sympathetic nervous system and catecholamines in the regulation of energy metabolism. American Journal of Clinical Nutrition 38, 1018-1024.

Miller, D. S., Mumford, P. \& Stock, J. (1967). Thermogenesis in overeating man. American Journal of Clinical Nutrition 20, 1223-1229.

Morgan, J. B. \& York, D. A. (1983). Thermic effect of feeding in relation to energy balance in man. Annals of Nutrition and Metabolism 27, 71-77.

Paul, A. A. \& Southgate, D. A. T. (1978). Mc Cance and Widdowson's The Composition of Foods. London: H.M. Stationery Office.

Pittet, P. G., Gygax, P. H. \& Jequier, E. (1974). Thermic effect of glucose and amino acids in man studied by direct and indirect calorimetry. British Journal of Nutrition 31, 343-349.

Ravussin, E., Bogardus, C., Schwartz, R. S., Robbins, D. C., Wolfe, R. R., Horton, E. S., Danforth, E. \& Sims, E. A. H. (1985). Glucose-induced thermogenesis and insulin resistance in man. International Journal of Obesity 9, $103-109$.

Rosenberg, K. \& Durnin, J. V. G. A. (1978). The effect of alcohol on resting metabolic rate. British Journal of Nutrition 40, 293-298.

Schutz, Y., Acheson, K. J. \& Jequier, E. (1985). Twenty-four-hour energy expenditure and thermogenesis: Response to progressive carbohydrate overfeeding in man. International Journal of Obesity 9, 111-114.

Schwartz, R. S., Ravussin, E., Massari, M., O'Connel, M. \& Robbins, D. C. (1985). The thermic effect of carbohydrate versus fat feeding in man. Metabolism 34, 285-293.

Segal, K. R. \& Gutin, B. (1983). Thermic effect of food and exercise in lean and obese women. Metabolism 32, $581-589$.

Swindells, Y. E (1972). The influence of activity and size of meals on caloric response in women. British Journal of Nutrition 27, 65-73.

Weir, J. B. de V. (1949). New method of calculating metabolic rate with special reference to protein metabolism. Journal of Physiology 109, 1-9.

Welle, S., Lilavivat, U. \& Campbell, R. C. (1981). Thermic effect of feeding in man: increased plasma norepinephrine levels following glucose but not protein or fat consumption. Metabolism 30, 953-957.

Zed, C. \& James, W. P. T. (1986). Dietary thermogenesis in obesity. Response to carbohydrate and protein meals: the effect of $\beta$-adrenergic blockade and semi-starvation. International Journal of Obesity 10, 391-405. 